\section{Edwin H. Fedder}

Edwin H. Fedder, a retired administrator and professor at the University of Missouri, St. Louis, died on December 1, 1999, after a long illness.

Ed was director of the Center for International Studies and professor of political science at UM-St. Louis when he retired in 1991. He joined the university in 1967 and developed the Center to promote internationalization of the campus and curriculum. He also had chaired the university's senate, the governing body for the campus.

Earlier, he taught at the University of Illinois, Champaign-Urbana, University of Pittsburgh, Ohio State University, and Hollins College.

An authority on alliances, NATO, U.S. foreign policy, and national security, he wrote numerous articles on these subjects for professional journals, as well as two booksNATO: The Dynamics of Alliance in the Postwar World and Defense Politics of the Atlantic Alliance.

Professor Fedder was a cofounder of the International Studies Association and a past president of its Midwestern and Southern chapters. He was a visiting fellow at the London School of Economics and a guest lecturer at more than two dozen foreign universities. He was also a member of the Committee on Atlantic Studies and a former chairman of that organization's North American chapter.

After retiring, he spent his time writing poetry, some of which was published in the Wisconsin Journal of Peace Studies, and much of which was written for his six beloved grandchildren. A few weeks before his death he finished pieces, in verse, on Fascism and the Vietnam War and demonstrated once again his wit, skepticism, and knowledge of history.

Professor Fedder was born and reared in Baltimore, where he learned valuable lessons from family and customers while working in his parents' grocery store, from the rabbis, and from working as a cab driver and fifth-grade teacher. He earned a bachelor's degree in political science from the University of Maryland, College Park and a master's degree and doctorate, both in political science, from American University.

Ed was a dedicated teacher who deeply influenced the lives of many of his students. He nurtured students and patiently helped them develop intellectually and academically. No one was better able than he at blending history, politics, personal relations, and humor to convey indelible insights about international relations. He was equally adept at teaching the nuances of international relations theory and the reality of current political developments in the world. He was unsurpassed at being able to use examples taken from the movies of Mel Brooks to explain the Treaty of Westphalia, the origins of the Great War, and post-Cold War U.S.-European relations. His anecdotal teaching style often puzzled students at first, but they quickly came to understand and appreciate the method that left such lasting lessons. Students invariably finished his classes with greater knowledge of, maturity in dealing with, and deeper concern for the human condition.

Many junior faculty members from all across the university succeeded in their efforts to secure tenure through his unfailing support and through his long service on the campus tenure and promotions committee. He fought vigorously to uphold standards while maintaining sensibility and vision.

Through his Ephemeral Committee on Purity of Conscience, he served the intellectual community with unofficial, unrelenting mockery of campus officialism, error, stupidity, pretension, hypocrisy, and arrogance. Using wit and creativity, he never failed to expose the nakedness of those who would be emperors.

$\mathrm{He}$ is survived by his wife of 46 years, Ruth Weger Fedder; a daughter, Jane Lazaroff; a son, David Fed- der; two brothers, Herb Fedder and Donald Fedder, both of Baltimore; a sister, Bonnie Safro, of Tamarac, Florida; and six grandchildren.

An endowed lecture series in foreign policy and international relations has been established in his honor at University of Missouri, St. Louis. Donations are welcomed in his memory.

Ed's wisdom and wit can not be replaced. We will miss him greatly and forever.

Dave Robertson
University of Missouri, St. Louis
Fred Pearson
Wayne State University
Marty Rochester
University of Missouri, St. Louis
Joel Glassman
University of Missouri, St. Louis
Bob Baumann
University of Missouri, St. Louis

\section{Everett Carll Ladd Jr.}

Everett Ladd, who died suddenly December 8, 1999, in Willimantic, Connecticut, was one of the bestknown political scientists of his generation. Those of us who knew Everett from his graduate school days in the small Cornell government department of the early $1960 \mathrm{~s}$ recognized that he was a very special person, and were never less than amazed by his energy, discipline, creativity, and ambition. We expected him to go far, and he did.

Watching him up close over many years together at the University of Connecticut, I never ceased to stand in awe of his capacity to do so much, so well, on so many fronts. No matter how one counts, Everett had several distinguished careers-as political scientist, as builder and administrator of a major academic research institute and data archive at the University of Connecticut, and as editor and journalist. From the late 70 s on, he was also a general public opinion guru to a host of national political commentators who called him frequently to pick his brain about "what the poll- 
ing data really mean." In many ways these roles were mutually reinforcing, but at times they also produced a good deal of stress and strain, especially toward the end, when his critical commentary on the polls taken during the 1996 election riled much of the commercial polling industry. He excelled in each of his careers, leaving a record of enormous accomplishment by any standard.

Everett was born in Saco, Maine, in 1937. He attended public schools there and graduated from Bates College in 1959. He received his Ph.D. in government from Cornell University in 1964. He arrived at UConn in that same year, and rose to the rank of full professor in just five years. Except for brief research appointments to the Hoover Institution and elsewhere, he spent his entire academic career at UConn. Over the years, many "feelers" and offers came. "Surely," it was speculated again and again, "he will go this time." But that time never came. The exactly right offer never came at the right moment. In truth, Everett was just too busy to move, and the university gave him everything he needed to do his work. After 1977, when the Roper Center was relocated to Storrs, there was no good reason for him to move anywhere else.

It is a rare thing for a person of Everett's academic stature to stay put for so long. As it happened, though, he became more and more firmly rooted in Storrs, and both he and the University of Connecticut gained much from their long association. For many years, up until his retirement shortly before his death, Everett was director of the Institute for Social Inquiry and executive director and president of the Roper Center for Public Opinion Research as well as a professor in the department of political science. He loved the university and was a loyal fan of its athletic teams through bad years and good. He traveled much less than his responsibilities and professional reputation permitted. On February 10, 2000, the university appropriately paid tribute to Everett by hosting a well-attended memorial service that gave considerable comfort to his family, associates, and friends at a most difficult time. His retirement and sudden death leave many big holes in the scheme of things in Storrs. It will take several people to try to fill them.

Everett's political science career got off to a very fast start. He published his first article while still a graduate student (a rare thing in those days) and began producing a steady stream of books, monographs, chapters, articles, and edited volumes that would not dry up until the end of his life. His books include Negro Political Leadership in the South (1966), Ideology in America (1969), American Political Parties (1970), The Divided Academy (1975, with S.M. Lipset), Transformations of the American Party System (1975, with C.D. Hadley), Where Have All the Voters Gone (1978), and The American Polity (1985), which became a best-selling text for American government courses and went through five editions. This last book's elegant style and authoritative sweep over the many subfields of American political science make it an exemplar of Everett's writing. He could achieve this level of excellence in a single-authored text because, throughout his scholarly career, he explored practically every topic that related to the theory and practice of the American political system.

In his books and other scholarly writings, Everett addressed big questions and reached wide audiences. He was among the first to see that the New Deal partisan alignment was, by the late $1960 \mathrm{~s}$, passing into history. The "something else" into which it was being transformed occupied him for the rest of his life. For three decades he tried to find the proper conceptual and theoretical language to capture what was happening to the American electoral order. Close readers of this part of his work will note many changes of mind along the way. At certain times, he would abandon the realignment concept entirely, seemingly taking some pleasure in throwing out American political science's equivalent to the theory of plate tectonics. Despite this, he would always revive realignment in some new form. As much as he will be remem- bered for his important contributions to the study of American electoral politics, he also will be acknowledged for shaping discussions of the causes of declining voter participation, the role of academics in politics, and the theory of postindustrial society.

Those who knew Everett well saw that he was powerfully motivated to study and weigh in on public questions about which he cared personally. Guiding his analysis of the mountains of data he collected on any subject he studied were concerns rooted in his strongly held personal values. Like his Cornell mentors, he worried little about "scientific value neutrality" as he sought to advance proper understanding of the civil rights revolution of the $60 \mathrm{~s}$, the turbulent politics of the Vietnam War period, or the ideological retrenchment of the Reagan era. Throughout all of his work there is an underlying, consistent commitment to Herbert Croly's conception of the American nation as "a novel and promising political creation ... precisely and entirely because it was a democratic nation-a nation committed by its institutions and aspirations to realize the American idea." Like Croly, Everett discerned a unique American dynamic through which leaders like Lincoln and Theodore Roosevelt carry the idea forward. In his younger years, Everett saw John F. Kennedy as such a leader. By the end of the $60 \mathrm{~s}$, however, his hopes had shifted to Richard Nixon and later to Ronald Reagan. Everett wrote about what is called "American exceptionalism" so often and so forcefully because he held its tenets so strongly. He really believed in the unique promise of American life. As time passed, the conservatism of his vision became more pronounced. Late in life, he seemed to colleagues who knew him best to be most comfortable with others who shared his views fully, and more drawn to forms of writing that permitted him to candidly express these views. He also seemed to feel more keenly a sense of disappointment when political events did not go as he thought they should, and to find it more difficult to draw a line between his analytic and more 
partisan judgments. None of this should be read as a disparagement of Everett's scholarly writing in the least. Rather, these observations are offered as illustrations of how his deep personal value commitments inspired him to work so hard and produce so much.

Everett left a large corpus of firstrate scholarship. If that were all he did, it would be enough to make him one of the most highly esteemed American political scientists of his time. Everett's scholarship brought him many well-deserved honors. Among them were fellowships from the Social Science Research Council, the Ford Foundation, the Guggenheim Foundation, the Rockefeller Foundation, the Hoover Institution, and the Center for Advanced Study in the Behavioral Sciences, as well as appointments to editorial boards, advisory committees, and other positions too numerous to mention.

But there was much more. Everett's second career as builder and adminstrator of a large and complex social science research institute and data archive began modestly with his creation of what he called the Social Science Data Center (SSDC) at UConn in 1968. At its founding, SSDC consisted of little more than some data sets Everett needed to do his work, a secretary, and a couple of graduate students. It is doubtful that he ever consciously intended to build the center into the Institute for Social Inquiry/Roper Center or devote so much of his time and energy to operating the ever-growing institution in his later years. It is also hard to think that anyone other than Everett could possess the talents necessary to bring off the transformation of his personal data archives into one of the world's foremost public opinion research and education centers.

Like other great institution-builders, Everett had vision and the drive necessary to get things done, sometimes against difficult odds, and he made most of the big decisions himself. Since he did not delegate easily, he remained the driving force of ISI/Roper even as its staff became very large. Everett was instrumental in building the now-immense Roper archive of survey data and ensuring relatively easy access to its contents through POLL, in establishing The Public Perspective magazine, developing The Connecticut Poll, and designing a new and successful M.A. program in survey research as well as a support system for graduate students in political science and other departments.

Everett Ladd was often a demanding taskmaster to staff and, at times, he was impatient with the collegial decision-making processes that faculty rightly desire. On the positive side, he did a lot of things that would otherwise have been left undone. The energy required to accomplish all he did was, of course, massive. And toward the end, Everett antagonized many in the polling industry by forcefully stating his strongly and honestly held views on polling in the larger context of American democracy, creating role conflicts that he found very difficult to resolve. Such difficulties may be unavoidable when one operates a world-class academic research enterprise of the sort that he had built. Despite occasional protestations, he enjoyed the work for many years, and through it he rightly became known as one of the most authoritative voices on American public opinion.

Everett's third career was that of journalist and editor. He published some of his earliest articles in The Nation magazine in the 1960s, and later published regularly in many other journals of opinion. In the late 70 s and early $80 \mathrm{~s}$, he wrote a number of feature articles for Fortune. From 1989 to 1995 , he wrote a regular series of columns for the Christian Science Monitor, producing more than a hundred columns for the paper on a vast range of subjects.

Everett was heavily involved with Public Opinion throughout its life, serving as consulting editor from 1977 to 1983 and as senior editor from 1983 until 1989. Throughout this period, he contributed many articles to the magazine and supervised its highly esteemed section on public opinion data, drawing mostly from the Roper archive in Storrs. Everett's proudest journalistic endeavor of all, though, was his editor- ship of The Public Perspective, which he held from 1989 until his retirement from the University of Connecticut. He took great interest in every aspect of the magazine's production, doing eveerything from encouraging authors to write on timely questions to editing submissions and supervising the layout to fighting the endless battle to eliminate typographical errors.

From the time he drafted his first Nation articles until his death, Everett found journalistic writing particularly satisfying because, I think, it allowed him to comment directly on important public questions while blending his judgments with the data he was analyzing. If he had chosen journalism as his principal career, he would surely have risen to the top of the profession as a national columnist. He wrote quickly, easily, and clearly, imposing the force of his considerable intellect on difficult subjects to get his point across in short order. It is not a skill that most academics possess.

Everett Ladd will be greatly missed by the many associates and colleagues who had the good fortune to work with him in his professional capacities. It is fitting, given his respect for the American creedal value system that he both understood as a scholar and affirmed as a person, to write, finally, that he was a truly creative individual-one who could accomplish more than it seemed possible for any single person to do. Watching him, one always wondered how he found enough time in his day to meet all his responsibilities. When he was at his best, his intelligence was truly formidable. I and other colleagues who enjoyed vigorous lunch-time conversations with him on such occasions would later say to one another that we had never known anyone quite like him. He was an intellectual whirlwind of incredible force at such moments. Everett was one of those rare individuals who simply can't be replaced.

W. Wayne Shannon University of Connecticut 